\title{
Thrombin Stimulates Tumor-Platelet Adhesion In Vitro and Metastasis In Vivo
}

M. L. Nierodzik, A. Plotkin, F. Kajumo, and S. Karpatkin

New York University Medical School, New York 10016

\begin{abstract}
Recent studies have revealed a role for platelets and the platelet-adhesive proteins, fibronectin and von Willebrand factor (vWF) in platelet-tumor cell interaction in vitro and metastasis in vivo. The present report documents the effect of thrombin treatment of platelets on this interaction in vitro and in vivo. In vitro, thrombin at $100-1,000 \mathrm{mU} / \mathrm{ml}$ maximally stimulated the adhesion of six different tumor cell lines from three different species two- to fivefold. As little as 1-10 $\mathrm{mU} / \mathrm{ml}$ was effective. The effect of thrombin was specific (inhibitable by hirudin, dansyl-arginine $N$-(3-ethyl-1,5 pentanediyl) amide and unreactive with the inactive thrombin analogue $N$-P-tosyl-L-phenylchloromethylketone-thrombin and D-phenylalanyl-L-propylL-arginine chloromethylketone-thrombin (PPACK-thrombin), and required high-affinity thrombin receptors (competition with PPACK-thrombin but not with $\boldsymbol{N}$-P-tosyl-L-lysine-chloromethyl-ketone-thrombin). Functionally active thrombin was required on the platelet surface. Binding of tumor cells to thrombin-activated platelets was inhibitable by agents known to interfere with the platelet GPIIb-GPIIIa integrin: monoclonal antibody 10E5, tetrapeptide RGDS and $\gamma$ chain fibrinogen decapeptide LGGAKQAGDV, as well as polyclonal antibodies against the platelet adhesive ligands, fibronectin and vWF. In vivo, thrombin at $250-500 \mathrm{mU}$ per animal increased murine pulmonary metastases fourfold with CT26 colon carcinoma cells and 68-413-fold with B16 amelanotic melanoma cells. Thus, thrombin amplifies tumor-platelet adhesion in vitro twoto fivefold via occupancy of high-affinity platelet thrombin receptors, and modulation of GPIIb-GPIIIa adhesion via an RGD-dependent mechanism. In vivo, thrombin enhances tumor metastases 4-413-fold with two different tumor cells lines. ( $J$. Clin. Invest. 1991. 87:229-236.). Key words: fibronectin • metastasis • platelet integrin • von Willebrand factor
\end{abstract}

\section{Introduction}

The requirement of platelets for murine pulmonary metastases was recognized by Gasic et al. (1) over 20 years ago and confirmed by our group in 1984 (2). However, the mechanism of the platelet requirement is poorly understood. In previous reports (1-3), an adequate platelet number was shown to be a

This study was presented in part at the 81st Annual Meeting of the American Society for Clinical Investigation, Washington, DC, on 1 May 1989 and has been published in abstract form (1989. Clin. Res. 37:548A).

Address reprint requests to Dr. Karpatkin, New York University Medical School, 550 First Avenue, New York, NY 10016.

Received for publication 26 January 1990 and in revised form 16 August 1990.

J. Clin. Invest.

(C) The American Society for Clinical Investigation, Inc.

0021-9738/91/01/0229/08 \$2.00

Volume 87, January 1991, 229-236 necessary requirement since induction of thrombocytopenia was shown to be associated with a decrease in the number of metastases, with a reconstitution of metastases after platelet repletion $(1,3,4)$. However, we have recently demonstrated that platelet adhesion and platelet-adhesive proteins must play a role, since a monoclonal antibody $10 \mathrm{E} 5$, directed against the common platelet-adhesive protein receptor for fibronectin, von Willebrand factor, and fibrinogen, GPIIb-GPIIIa (a member of the integrin family $[5,6])$, could inhibit the metastases of CT26 colon carcinoma in thrombocytopenic mice repleted with human platelets, and a polyclonal antibody against murine von Willebrand factor was capable of inhibiting metastases of CT26, B16 amelanotic melanoma, and T241 Lewis bladder cells without the induction of thrombocytopenia (4). In addition, we have demonstrated that murine CT2 6 cells or human HCT8 colon carcinoma are capable of adhering to adherent platelets on plastic microtiter wells, and that this adhesion can be inhibited by monoclonal antibody $10 \mathrm{E} 5$, plus polyclonal antibodies against fibronectin and von Willebrand factor, as well as tetrapeptide RGDS that appears to be the binding domain for the three adhesive proteins (4). The role of platelettumor adhesion $(4,7)$ and/or platelet-tumor-subendothelial matrix adhesion in metastases has recently been supported by the observation of Humphries et al. (7) who noted a 67-97\% inhibition of murine pulmonary metastases with the fibronectin binding domain pentapeptide GRGDS, employing B16F10 melanoma cells.

Because of this information, we postulated that platelet tumor interaction might be mediated via adhesion of tumor cells via tumor cell integrin receptors to the platelet-adhesive proteins: fibronectin and von Willebrand factor which have bound to the platelet GPIIb-GPIIIa integrin receptor, after the spreading of platelets. Adherent platelets are known to have partially released their $\alpha$ granule content (8). If this were the case, we further postulated that thrombin treatment of adherent platelets would enhance tumor cell adhesion via further release of fibronectin and von Willebrand factor, would enhance exposure of the GPIIb-GPIIIa receptor $(9,10)$, and would increase tumor metastasis in vivo.

The present report ( $a$ ) documents the enhanced binding of six different tumor cell lines to adherent platelets in vitro after thrombin treatment of platelets and demonstrates the enhanced adhesion that is dependent upon platelet GPIIb-GPIIIa adhesion via an RGD mechanism; $(b)$ documents the enhanced murine metastases in vivo of two different tumor cell lines after the infusion of tumor cells plus thrombin.

\section{Methods}

Tumor cell lines and tissue culture media. CT26, $N$-nitroso- $N$-methylurethane-induced mouse undifferentiated colon carcinoma cells (11), were obtained through the courtesy of Dr. M. H. Goldrosen, Roswell Park Memorial Institute, Buffalo, NY, and grown in RPMI 1640 containing 10\% fetal bovine serum (FBS) (Gibco Laboratories, Grand Island, NY). HCT8 spontaneous human colon adenocarcinoma cells 
were obtained through the courtesy of Dr. E. Cadman, Yale University Medical School, New Haven, CT, and grown in the same medium as CT 26 cells. HM29 and HM54 hamster malignant melanoma cells were obtained through the courtesy of Dr. Jean-Claude Bystryn, New York University Medical Center. SK-Mel 28 human melanoma cells were obtained from American Type Culture Collection, Rockville, MD. All three melanoma cell lines were grown in RPMI 1640 with $1 \%$ penicillin-streptomycin, 2\% glutamine, and 10\% FBS (Gibco Laboratories) and $1 \%$ nonessential amino acids, Sigma Chemical Co., St. Louis, MO. KLN205 murine squamous cell carcinoma (12) was obtained from American Type Culture Collection, and grown in minimal essential medium with $1 \%$ penicillin-streptomycin, $2 \%$ glutamine, 10\% FBS, and $1 \%$ nonessential amino acids.

Anti-platelet-adhesive protein receptor and adhesive protein reagents. Monoclonal antibodies 10E5 and 6D1 were provided through the courtesy of Dr. Barry Coller, State University of New York, Stony Brook, NY. 10E5 binds to the GPIIb-GPIIIa complex and inhibits the binding of fibrinogen, fibronectin, and von Willebrand factor to activated platelets (13). $6 \mathrm{D} 1$, used as a control monoclonal antibody, binds to GPIb and inhibits ristocetin-induced platelet aggregation (14). Monospecific anti-human fibronectin antibody was raised in rabbits immunized with human fibronectin purified by Sepharose 4B gel filtration and gelatin-Sepharose 4B affinity chromatography. The details of fibronectin purification and antibody production have been described previously (4). Human von Willebrand factor was purified by the method of Thorell and Blomback (15). Anti-human von Willebrand factor antibody was purchased from Calbiochem-Behring Corp., San Diego, CA. It had no reactivity on ELISA with fibronectin at a concentration of $500 \mathrm{ng} / \mathrm{ml}$, whereas it was capable of detecting von Willebrand factor at a concentration of $30 \mathrm{ng} / \mathrm{ml}$. RGDS and the decapeptide of the $\gamma$ chain of fibrinogen (LGGAKQAGDV), 402-411, and a 9-mer control peptide (QKMPFSLVG) were kindly synthesized for us by Dr. David Schlesinger, New York University Medical Center, and purified by gel filtration on a G25 sephadex column. Amino acid composition and sequence were verified by amino acid analyser. GRGES was obtained from Peninsula Laboratories, Inc., Belmont, CA.

Thrombin and anti-thrombin reagents. Human thrombin $(3,000$ NIH U/mg), $N$-P-tosyl-L-lysine chloromethylketone (TLCK), ${ }^{1} N$-P-tosyl-L-phenyl chloromethylketone (TPCK), and hirudin were purchased from Sigma. D-Phenylalanyl-L-propyl-L-arginine chloromethylketone (PPACK) was obtained from Calbiochem-Behring Corp. Dansyl-arginine $N$-(3-ethyl-1,5 pentanediyl) amide (DAPA), a potent competitive inhibitor of thrombin (16), was a gift of Dr. Michael Nesheim, Queens University, Ontario, Canada. TLCK, TPCK, and PPACK bind to the active protease site of thrombin. PPACK-thrombin has been shown to bind to high-, moderate-, and low-affinity thrombin receptors on platelets, whereas TLCK-thrombin has been shown to bind to low- and moderate-affinity receptors $(17,18)$. TLCK-thrombin was prepared as described by Workman et al. (19). This was followed by overnight storage at $4^{\circ} \mathrm{C}$, dialysis against 4 liters of water for $24 \mathrm{~h}$, followed by two 4-liter exchanges against PBS for $24 \mathrm{~h}$ each. TPCK-thrombin was similarly prepared. PPACK-thrombin was prepared by dissolving $50 \mu \mathrm{g}$ of PPACK and $3.3 \mu \mathrm{g}$ of thrombin in $5 \mathrm{ml}$ of $0.3 \mathrm{M}$ sodium phosphate buffer, $\mathrm{pH} 7.4$ and dialyzing against $0.38 \mathrm{M} \mathrm{NaCl}, 0.36 \mathrm{mM}$ sodium

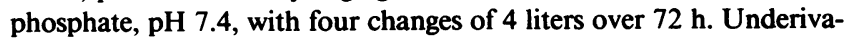
tized thrombin was similarly diluted and dialyzed for control experiments. Derivatized thrombins gave plasma clotting times $>5 \mathrm{~min}$, whereas underivatized thrombin, similarly dialyzed, gave a clotting time of 15-17 s at the same concentration.

Preparation of platelets. Human platelets were separated from citrated platelet-rich plasma $(0.38 \%$ final concentration) on a $10 \%$ and $20 \%$ discontinuous Stractan gradient (arabino-galactan polymer) dis-

1. Abbreviations used in this paper: DAPA, dansyl-arginine $N$-(3-ethyl1,5-pentanediyl) amide; PPACK, D-phenylalanyl-L-propyl-L-arginine chloromethylketone; TLCK, $N$-P-tosyl-L-lysine chloromethylketone; TPCK, $N$-P-tosyl-L-phenyl chloromethylketone. solved in an isotonic balanced salt solution, as described in detail, previously (4).

In vitro platelet-tumor cell adhesion assay. $100 \mu \mathrm{l}$ of $3 \times 10^{7}$ platelets were applied to 96-well flat-bottom microtiter plates (model 3072, Falcon Labware, Oxnard, CA) and treated with thrombin, or the thrombin analogues TLCK-thrombin, TPCK-thrombin, PPACKthrombin, or a mixture of thrombin with the thrombin inhibitors, hirudin or DAPA, within $1 \mathrm{~h}$ at room temperature and incubated overnight at $4^{\circ} \mathrm{C}$. The plastic wells were then blocked with $0.01 \mathrm{M} \mathrm{PBS}, \mathrm{pH} 7.4$ containing $1 \%$ bovine serum albumin (BSA) for $1 \mathrm{~h}$ at $37^{\circ} \mathrm{C}$, followed by one wash of the above and three washes of PBS containing $0.9 \mathrm{mM}$ $\mathrm{CaCl}_{2}$ and $0.9 \mathrm{mM} \mathrm{MgCl}$. The platelets were then incubated with various inhibitors or their vehicle for $1 \mathrm{~h}$ at $37^{\circ} \mathrm{C}$ before the addition of $100 \mu \mathrm{l}$ of $1 \times 10^{5}$ tumor cells, suspended in PBS-Ca-Mg, for $1 \mathrm{~h}$ at $37^{\circ} \mathrm{C}$. The plates were then washed twice with the same buffer to remove nonadherent cells, the adherent cells removed with trypsin-EDTA (Gibco Laboratories) and enumerated in a hemocytometer under phase microscopy. All experiments were performed in triplicate, and the data were averaged.

Thrombin assay. $0.5 \mathrm{ml}$ of plasma anticoagulated with $0.38 \%$ sodium citrate was incubated at $37^{\circ} \mathrm{C}$ for $5 \mathrm{~min}$ before the addition of 0.5 $\mathrm{ml}$ of thrombin or its analogue diluted in PBS. $1 \mathrm{U}$ of thrombin gave a clotting time of $15 \mathrm{~s}$.

ELISA assay for tumor cell surface fibronectin. An inhibition assay was employed in which purified fibronectin was applied to plastic microtitre wells at a concentration of $0.5 \mu \mathrm{g}$ per well in PBS, pH 7.4, and allowed to incubate overnight at $4^{\circ} \mathrm{C}$. Anti-fibronectin antibody, 6 $\mu \mathrm{g} / \mathrm{ml}$ of purified $\mathrm{IgG}$, was then incubated with standard concentrations of fibronectin, $0.1-12 \mu \mathrm{g} / \mathrm{ml}$ or varying dilutions of tumor cells, 5 $\times 10^{4}$ to $4 \times 10^{2}$ for $1 \mathrm{~h}$ at $37^{\circ} \mathrm{C}$. The supernatant was then applied to microtiter plates coated with fibronectin. A goat anti-rabbit IgG alkaline-phosphatase conjugate was then applied at a 1:1,000 dilution (Sigma Chemical Co.) and the appropriate substrate (Sigma Chemical Co.) applied for color development at $405 \mathrm{~nm}$. Microtiter slides were read with a Microplate reader (Dynatech Laboratories, Inc., Alexandria, VA). The assay was sensitive at $2 \mathrm{ng} / \mathrm{ml}$. In a direct ELISA assay this anti-fibronectin antibody did not react with von Willebrand factor at $500 \mathrm{ng} / \mathrm{ml}$.

ELISA assay for platelet surface GPIIb-GPIIIa. Adherent platelets as prepared in the adhesion assay were reacted with monoclonal antibody $10 \mathrm{E} 5$ at $5 \mu \mathrm{g} / \mathrm{ml}$, washed in PBS/BSA, and then reacted with a goat anti-mouse IgG $(1: 1,000)$ antibody conjugated with alkaline phosphatase (Sigma Chemical Co.). Appropriate substrate was added and color development assayed as above.

Preparation of GPIIb-GPIIIa. Triton-solubilized platelet extracts were prepared from outdated Tisch Hospital Blood Bank platelets. Centrifuged platelets were washed in a modified human Ringer solution (20) containing the protease inhibitors: $10 \mathrm{mM}$ EDTA, $10 \mathrm{mM}$ benzamidine, $100 \mu \mathrm{g} / \mathrm{ml}$ soybean trypsin inhibitor, and $0.1 \mathrm{mM}$ PMSF, and solubilized in the same solution to which $1 \%$ Triton X-100 has been added. This extract was sonicated at $4^{\circ} \mathrm{C}$ for $20-30 \mathrm{~s}$ at $60 \mathrm{~W}$, and then allowed to stand for $1 \mathrm{~h}$ at $4^{\circ} \mathrm{C}$. It was then ultracentrifuged at $100,000 \mathrm{~g}$ for $1 \mathrm{~h}$ at $4^{\circ} \mathrm{C}$ and the supernatant employed. GPIIb-GPIIIa was purified by affinity chromatography on concanavalin A sepharose 4B beads $(21,22)$, followed by heparin-Sepharose 6B affinity chromatography (22). The purified products were $>95 \%$ GPIIb and GPIIIa on $10 \%$ SDS-PAGE stained with Coomassie Blue.

In vivo metastatic studies. Experiments were performed as described previously (23). Tumor cells were removed from subconfluent tissue culture dishes with trypsin-EDTA, washed in PBS- $\mathrm{Ca}^{++}-\mathrm{Mg}^{++}$ and examined for viability with trypan blue. $25,000-50,000$ viable tumor cells, suspended in $250-500 \mathrm{mU}$ of thrombin in $\mathrm{PBS}-\mathrm{Ca}^{++}-\mathrm{Mg}^{++}$, or $\mathrm{PBS}_{-} \mathrm{Ca}^{++}-\mathrm{Mg}^{++}$vehicle were injected intravenously into the tail vein of syngeneic BALB/c or C57B1/65 mice in a volume of $200 \mu$. Control and experimental mice were injected alternately to avoid the bias of possible changes in in vivo metastatic potential after in vitro storage at $4^{\circ} \mathrm{C}(23)$. Animals were killed on day 28 and the lungs were 
removed and fixed in Perfix (Fisher Scientific Co., Springfield, NJ) for $24 \mathrm{~h}$ before enumeration of metastases macroscopically or microscopically. For macroscopic examination, surface number and diameter of nodules were classified into five categories $<0.1 \mathrm{~mm},>1<2 \mathrm{~mm}$, $>2<3 \mathrm{~mm},>3<4 \mathrm{~mm}$, and $>4 \mathrm{~mm}$. The volume of each nodule was calculated from its diameter, assuming a sphere. The mean nodule volume for each mouse was calculated by dividing the total nodule volume for each group of mice by the number of mice in each group. Tumor mass was calculated by multiplying the mean nodule number by the mean nodule volume per lung.

Microscopic examination was performed in some experiments. The fixed lungs were embedded with paraffin in a uni-cassette (Miles Laboratories, Inc., Elkhart, IN), and three coronal slices, $3 \mu \mathrm{m}$ thick, made through the lung. The pathologic specimen was stained with hematoxylin-eosin and the largest slice enumerated for number and surface area of tumor foci. Surface area of each metastatic focus was calculated with a micrometer by multiplying the largest two diameters at right angles to each other.

\section{Results}

Effect of thrombin activation of adherent platelets on tumor cell adhesion. Fig. 1 demonstrates the effect of increasing concentration of thrombin on the adhesion of HM54 melanoma tumor cells to human platelets. Note the exquisite sensitivity of thrombin-treated platelets to tumor cell adhesion: ca. twofold enhancement of adhesion with as little as $1-10 \mathrm{mU} / \mathrm{ml}$ of thrombin $(P<0.05$ and $<0.03$ respectively, paired Student $t$ test), with optimum 4.7 -fold enhancement at $100 \mathrm{mU} / \mathrm{ml}$ thrombin $(P<0.001)$.

Similar results were obtained with HM29 melanoma cells, 4.0-fold enhancement at $1,000 \mathrm{mU} / \mathrm{ml}, n=15(P<0.001)$; CT26 colon carcinoma cells, 3.4-fold enhancement at 100 $\mathrm{mU} / \mathrm{ml}, n=3$; KLN205 squamous carcinoma cells, 2.4-fold enhancement at $500 \mathrm{mU} / \mathrm{ml}, n=3$; B16 amelanotic melanoma cells, 3.3-fold enhancement at $500 \mathrm{mU} / \mathrm{ml}, n=3$; and HCT 8 colon carcinoma cells, 2.1-fold enhancement at 500 $\mathrm{mU} / \mathrm{ml}, n=3$ (Table I).

Specificity of thrombin activation. Activation of tumor cell adhesion by thrombin-treated adherent platelets was specific for thrombin (Table II). Thus, although thrombin at $100 \mathrm{mU} /$ ml enhanced HM54 melanoma cell adhesion threefold, the

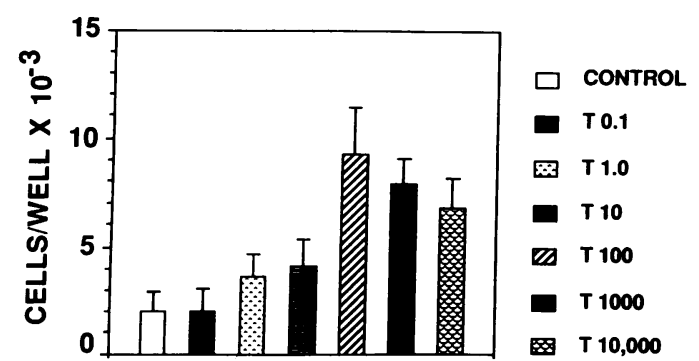

Figure 1. Effect of thrombin treatment of platelets on adhesion of HM54 melanoma cells to platelets. $3 \times 10^{7}$ stractan-separated platelets were applied to microtiter plates at $22^{\circ} \mathrm{C}$ for $1 \mathrm{~h}$, followed by the addition of thrombin $(\mathrm{T})$ at the designated concentrations (in milliunits per milliter). After $18 \mathrm{~h}$ of overnight incubation at $4^{\circ} \mathrm{C}$, the platelets were washed and blocked with PBS-1\% BSA, followed by the addition of $1 \times 10^{5}$ HM54 melanoma cells in PBS- $0.9 \mathrm{mM}$ $\mathrm{MgCl}_{2}+0.9 \mathrm{mM} \mathrm{CaCl}_{2}$ for $1 \mathrm{~h}$ at $37^{\circ} \mathrm{C}$. Nonadherent cells were removed by washing. Adherent cells were removed with trypsinEDTA and enumerated by phase microscopy $(n=5)$.
Table I. Effect of Thrombin on Adhesion of Tumor Cells to Platelets Thrombin Dose

\begin{tabular}{|c|c|c|c|c|c|c|c|c|}
\hline \multirow[b]{3}{*}{$n$} & \multirow[b]{3}{*}{ Tumor cell } & \multicolumn{6}{|c|}{ Concentration } & \multirow{3}{*}{$\begin{array}{l}\text { Maximum folc } \\
\text { increase }\end{array}$} \\
\hline & & \multicolumn{6}{|c|}{$m U / m l$} & \\
\hline & & 0 & 50 & 100 & 250 & 500 & 1,000 & \\
\hline \multicolumn{9}{|c|}{$\times 10^{-3}$ per well } \\
\hline \multirow[t]{2}{*}{15} & HM29 & 5.5 & & & & & 21.9 & 4.0 \\
\hline & & \pm 0.7 & & & & & \pm 2.6 & \\
\hline \multirow[t]{2}{*}{3} & СТ26 & 4.9 & 11.6 & 16.7 & & & 15.5 & 3.4 \\
\hline & & \pm 1.9 & \pm 2.6 & \pm 2.9 & & & \pm 4.8 & \\
\hline \multirow[t]{2}{*}{3} & KLN205 & 3.1 & 3.9 & 5.2 & 6.6 & 7.4 & 4.3 & 2.4 \\
\hline & & \pm 1.5 & \pm 2.1 & \pm 2.3 & \pm 3.6 & \pm 2.8 & \pm 0.2 & \\
\hline \multirow[t]{2}{*}{3} & B16a & 5.4 & & & & 17.8 & 12.8 & 3.3 \\
\hline & & \pm 2.7 & & & & \pm 6.3 & \pm 4.2 & \\
\hline \multirow[t]{2}{*}{3} & НСТ8 & 4.7 & & & & 9.8 & 9.4 & 2.1 \\
\hline & & \pm 0.9 & & & & \pm 1.9 & \pm 0.3 & \\
\hline
\end{tabular}

A lawn of adherent platelets, prepared as in Fig. 1, was treated with varying concentrations of thrombin overnight at $4^{\circ} \mathrm{C}$, before the addition of $1 \times 10^{5}$ tumor cells and enumeration of adherent cells, $\times 10^{-3} /$ well. SEM is given.

inactive thrombin analogues (plasma clotting time $>5 \mathrm{~min}$ ), TPCK-thrombin and PPACK-thrombin, had no effect at similar concentration, nor did mixtures of the thrombin inhibitor, hirudin $(0.1 \mathrm{U} / \mathrm{ml})$ plus thrombin or DAPA $\left(10^{-6} \mathrm{M}\right)$ plus thrombin.

Requirement of active thrombin on the platelet surface. Experiments were next designed to determine whether active thrombin was bound to the platelet and required for tumor cell adhesion, or whether the effect of thrombin activation persisted after thrombin inactivation with DAPA. Fig. 2 demonstrates the requirement of active thrombin on the platelet surface for enhanced tumor cell adhesion. Thus, although thrombin-treated platelets enhanced HM29 tumor cell adhesion 2.5 -fold $(n=6, P<0.05)$ and preincubation of thrombin with 1 $\times 10^{-6} \mathrm{M}$ DAPA before addition to platelets prevented this effect, the effect was also prevented by addition of DAPA $18 \mathrm{~h}$ after thrombin activation of platelets $(n=6, P<0.05)$.

Requirement of high-affinity thrombin receptors. The relative affinity of the platelet thrombin binding site for tumor cell adhesion was investigated by examining the differential competitive effect of TLCK-thrombin vs. PPACK-thrombin, since PPACK-thrombin has been shown to bind to high-affinity

Table II. Effect of Thrombin and Thrombin Inhibitor Treatment of Platelets on Adhesion of HM54 Melanoma Cells to Platelets

\begin{tabular}{lccccc}
\hline \multicolumn{5}{c}{ Adherent cells } \\
\hline Control & Thrombin & $\begin{array}{c}\text { TPCK- } \\
\text { thrombin }\end{array}$ & $\begin{array}{c}\text { PPACK- } \\
\text { thrombin }\end{array}$ & $\begin{array}{c}\text { Hirudin- } \\
\text { thrombin }\end{array}$ & DAPA \\
\hline & \multicolumn{5}{c}{$\times 10^{-3} /$ well } \\
$4.8 \pm 1.7$ & $14.3 \pm 4.9$ & $4.3 \pm 1.7$ & $5.9 \pm 3.2$ & $4.7 \pm 3.0$ & $3.2 \pm 1.3$ \\
\hline
\end{tabular}

Adherent platelets were treated with thrombin or its inhibitors, as in Fig. 1. Thrombin, its analogues or hirudin, were employed at 100 $\mathrm{mU} / \mathrm{ml}$. DAPA was employed at $1 \times 10^{-6} \mathrm{M}(n=4)$. 


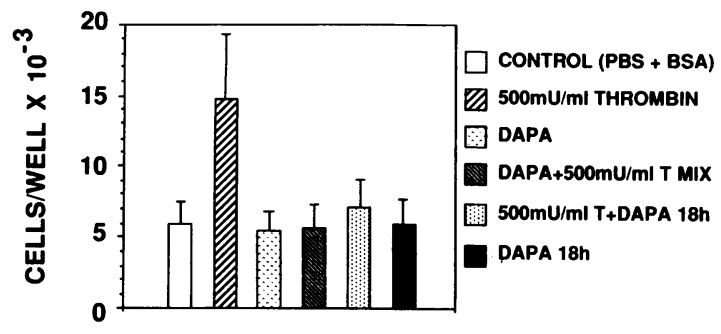

Figure 2. Effect of thrombin treatment of platelets and thrombin plus DAPA treatment on adhesion of HM29 melanoma cells to platelets. DAPA is a highly specific competitive inhibitor of thrombin. Reading from left to right, the bars represent: first bar, control adhesion of tumor cells to a platelet lawn; second bar, thrombin-treatment of the platelets with $500 \mathrm{mU}$ thrombin/ml for $18 \mathrm{~h}$; third bar, DAPA (1 $\mu \mathrm{M})$ treatment of platelets for $18 \mathrm{~h}$; fourth bar, treatment of platelets with a preincubated mixture of $500 \mathrm{mU} / \mathrm{ml}$ thrombin plus DAPA for $18 \mathrm{~h}$ before addition to tumor cells; fifth bar addition of DAPA $18 \mathrm{~h}$ after the addition of thrombin and immediately after washing nonadherent thrombin from the platelet lawn; sixth bar, addition of DAPA to platelets preincubated with buffer for $18 \mathrm{~h}(n=6)$.

thrombin receptor sites on platelets, whereas TLCK-thrombin does not $(17,18)$. Accordingly, competition experiments were performed in which the thrombin analogue, held constant at $500 \mathrm{mU} / \mathrm{ml}$, was preincubated with active thrombin at 25-500 $\mathrm{mU} / \mathrm{ml}$ for $15 \mathrm{~min}$ before their addition to adherent platelets, and subsequent tumor cell adhesion was assayed. Fig. $3 a$ demonstrates a competitive effect with the high-affinity PPACKthrombin, and Fig. $3 b$ demonstrates a noncompetitive effect with the low to moderate affinity TLCK-thrombin.
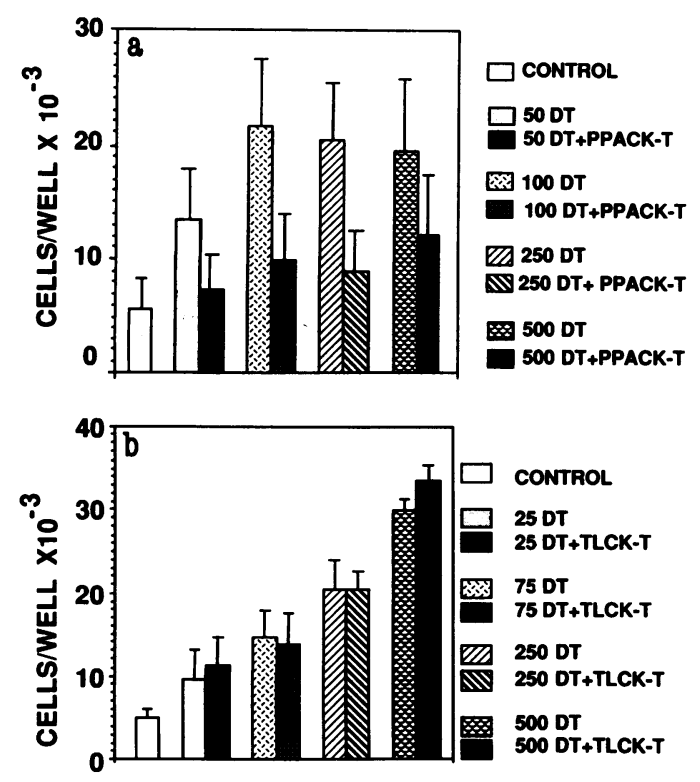

Figure 3. Effect of PPACK-thrombin (T) and TLCK-thrombin (T) at concentrations in milliunits per milliter on adhesion of HM54 melanoma cells to thrombin-treated platelets. (a) PPACK-thrombin was held constant at $500 \mathrm{mU} / \mathrm{ml}$ and active thrombin varied at 50 to $500 \mathrm{mU} / \mathrm{ml}$. Both thrombins were preincubated with each other for $15 \mathrm{~min}$ at $22^{\circ} \mathrm{C}$ before their addition to a lawn of platelets as in Fig. 1, and the number of adherent tumor cells was compared to the effect of similar concentrations of thrombin preincubated with buffer alone $(n=5)$. (b) Similar experiments with TLCK-thrombin $(n=3)$.
Effect of monoclonal antibody 10E5, RGDS, and decapeptide of gamma chain fibrinogen on adhesion of tumor cells to thrombin-activated platelets. Fig. 4 demonstrates the inhibitory effect of agents that inhibit the platelet GPIIb-GPIIIa receptor, monoclonal antibody 10E5 $(P=0.002), \operatorname{RGDS}(P=0.01)$ and $\gamma$ fibrinogen decapeptide $(P=0.03)$, on adhesion of HM29 tumor cells to thrombin-activated platelets. These were employed at maximum inhibitory concentrations. No effect was noted with 6D1, a monoclonal antibody that binds to GPIb, the peptide GRGES which does not bind to GPIIb-GPIIla or irrelevant 9-mer peptide.

Adhesion of tumor cells to GPIIb-GPIIIa. Because agents that inhibit the GPIIb-GPIIIa receptor inhibit binding of tumor cells to thrombin-activated platelets, it was necessary to determine whether tumor cells were capable of binding directly to GPIIb-GPIIIa. A 2.6-fold increase in binding was noted when $0.5 \mu \mathrm{g}$ of GPIIb-GPIIla was added to the microtiter plate, i.e., $3.7 \pm 0.4 \times 10^{3} \mathrm{HM} 29$ cells bound per well compared with $1.4 \pm 0.2 \times 10^{3}$ cells bound to PBS-BSA blocked wells, $n=12, P$ $<0.001$. This could have been secondary to fibronectin or some unknown ligand on the tumor cell surface. However, fibronectin was not detectable at a detection sensitivity of 0.4 ng per $10^{4}$ HM29 tumor cells.

Effect of thrombin on platelet surface GPIIb-GPIIIa. It has recently been reported that thrombin enhances the number of GPIIb-GPIIIa receptors on the platelet surface $(9,10)$. Because of the thrombin effect on tumor cell adhesion to adherent platelets, we elected to measure the effect of thrombin on the GPIIbGPIIIa receptor density of adherent platelets. Employing monoclonal antibody 10E5 in an ELISA assay, the microtiter well $O D$ at $405 \mathrm{~nm}$ increased from $0.170 \pm 0.039$ to $0.343 \pm 0.053$ or 2.0 -fold, $P=0.002, n=10$, after treatment of platelets with $100 \mathrm{mU} / \mathrm{ml}$ thrombin as in the adhesion assay.

Effect of polyclonal anti-fibronectin and anti-von Willebrand factor antibodies on adhesion of tumor cells to thrombinactivated platelets. Fig. 5 demonstrates the inhibitory effect of agents that inhibit the GPIIb-GPIIIa receptor ligands (employed at maximum inhibitory concentration): anti-fibronectin $(P=0.02)$ and anti-von Willebrand factor antibody $(P$ $=0.03$ ) on adhesion of HM29 melanoma tumor cells to thrombin-activated platelets.

Adhesion of tumor cells to fibronectin and von Willebrand factor. The inhibitory effect of anti-fibronectin and anti-von Willebrand antibodies on adhesion of tumor cells to thrombin-

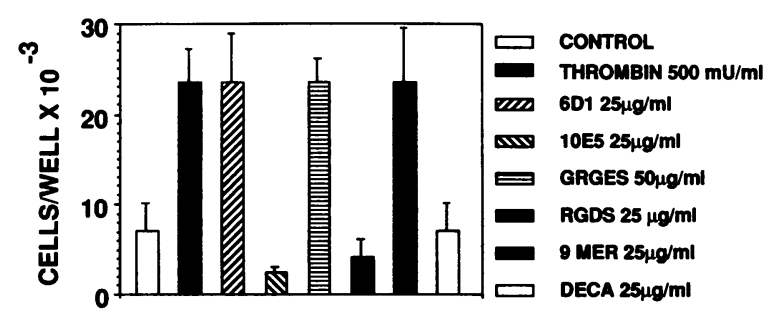

Figure 4. Effect of 10E5, RGDS, and $\gamma$ chain fibrinogen decapeptide (or control reagents: 6D1, GRGES, 9-mer peptide) on adhesion of HM29 melanoma cells to thrombin-treated platelets. Platelets were applied to a microtiter plate and treated with thrombin, $1 \mathrm{U} / \mathrm{ml}$ for $18 \mathrm{~h}$ as in Fig. 1. Platelets were then washed in PBS-1\% BSA, treated with $10 \mathrm{E} 5$ or $6 \mathrm{Dl}(25 \mu \mathrm{g} / \mathrm{ml})$, RGDS or GRGES $(50 \mu \mathrm{g} / \mathrm{ml})$ decapeptide or 9 -mer peptide $(25 \mu \mathrm{g} / \mathrm{ml})$ for $1 \mathrm{~h}$ at $37^{\circ} \mathrm{C}$ and rewashed before the addition of HM29 cells to platelets $(n=6)$. 


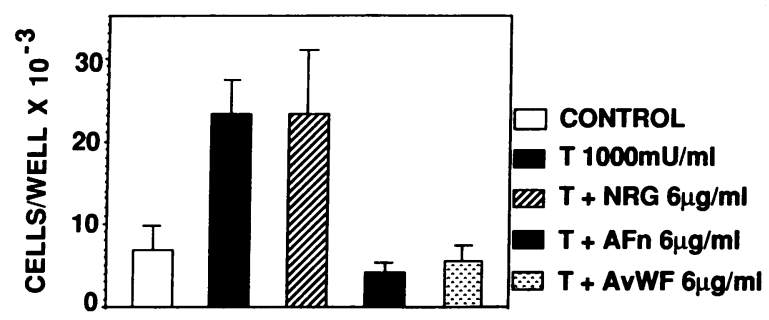

Figure 5. Effect of anti-fibronectin and anti-von Willebrand factor antibody on adhesion of HM29 melanoma cells to thrombin-treated platelets. Thrombin-treated platelets $(1 \mathrm{U} / \mathrm{ml})$, prepared as above, were washed, and then treated with PBS-BSA or purified IgG (6 $\mu \mathrm{g} /$ $\mathrm{ml}$ ) of either normal rabbit serum, anti-fibronectin serum, or antivon Willebrand factor serum for $1 \mathrm{~h}$ at $37^{\circ} \mathrm{C}$. Platelets were then washed, HM54 cells were added, and adherent cells were enumerated, as above $(n=6)$.

activated platelets suggested that tumor cells were binding to additionally released fibronectin and von Willebrand factor, as well as other possible ligands that have bound to the platelet surface; this could be via binding of these ligands to unoccupied GPIIb-GPIIIa sites or via binding to newly exposed GPIIb-GPIIIa receptors, as has recently been reported with thrombin $(9,10)$. Accordingly, specific binding of tumor cells to adhesive ligand was tested. Fig. 6 demonstrates the binding of three different tumor cell lines to fibronectin as well as von Willebrand factor-coated microtiter plates. Tumor cell binding to fibronectin was associated with spreading of tumor cells, whereas tumor cell binding to von Willebrand factor did not elicit spreading. In general, tumor cell binding to fibronectin was 1.5-2.9-fold greater for fibronectin compared to von Wil- lebrand factor for HM29, CT26 and HCT8 tumor cells (data not shown). Specificity of binding was demonstrated for fibronectin (Table III) by inhibition with a monospecific anti-fibronectin antibody for HCT8 $(P<0.001)$, CT26 $(P=0.01)$, and HM54, with lack of inhibition with a monospecific antivon Willebrand factor antibody. Specificity of binding was demonstrated for von Willebrand factor (Table III) by inhibition with a monospecific anti-von Willebrand factor antibody for HCT8 $(P=0.007)$, CT26 $(P<0.01)$, and HM29 $(P=0.02)$ with lack of inhibition with a monospecific anti-fibronectin antibody.

Effect of thrombin in vivo on pulmonary metastases of CT26 colon carcinoma and B16a amelanotic melanoma cells in syngeneic mice. The pathophysiologic relevance of the thrombin effect in vitro was next tested in vivo by infusion of both thrombin and two different tumors into syngeneic mice. Table IV demonstrates that thrombin stimulates metastases by increasing the product of the number and volume of pulmonary metastases (tumor mass) of CT26 colon carcinoma 4.3-fold (expt. 1) and B16a amelanotic melanoma 68-fold (expt. 2), when tumor metastases were enumerated macroscopically. A more detailed microscopic examination of a histological section of the entire pulmonary system revealed an even greater increase in metastases for B16a amelanotic melanoma of 413-fold (expt. 3).

\section{Discussion}

These data indicate that tumor cell adhesion to platelets (4) can be stimulated two- to fivefold by treatment of adherent platelets with thrombin. The effect was noted with all six tumor cells tested which included three melanoma cell lines, two colon
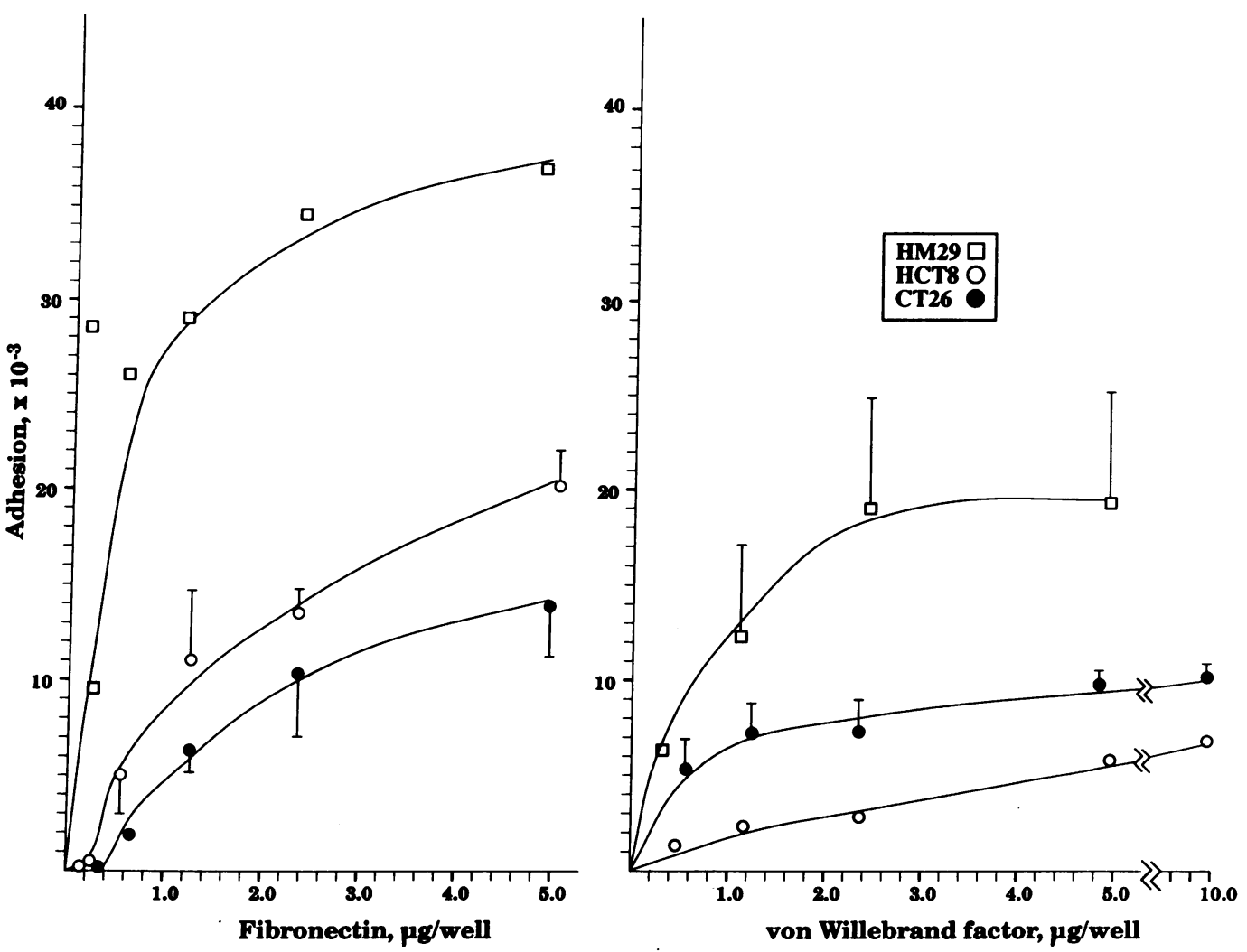

Figure 6. Specific adhesion of tumor cells to $(A)$ fibronectin or $(B)$ von Willebrand factorcoated microtiter wells. Microtiter plates were incubated with varying concentrations of ligand in PBS overnight at $4^{\circ} \mathrm{C}$, washed with PBSBSA and then treated with $1 \times 10^{5}$ tumor cells on fibronectin (CT26, $n=4 ; \mathrm{HCT} 8, n=4$ HM29, $n=2$ ) and on von Willebrand factor (CT26, $n=4$; HCT $8, n$ $=2 ; \mathrm{HM} 29, n=6$ ) for $1 \mathrm{~h}$ at $37^{\circ} \mathrm{C}$.

Nonadherent cells were washed away and adherent cells were enumerated per well $\times 10^{-3}$, as in Fig. 1 . 
Table III. Effect of Anti-Fibronectin and Anti-von Willebrand Factor Antibodies on Adhesion of CT26, HCT8, HM29, and HM54 Tumor Cells to Fibronectin and von Willebrand Factor

\begin{tabular}{|c|c|c|c|c|c|c|c|c|}
\hline \multirow[b]{3}{*}{$n$} & \multirow[b]{3}{*}{ Tumor } & \multirow[b]{3}{*}{ Buffer } & \multicolumn{2}{|c|}{ Normal rabbit IgG } & \multicolumn{2}{|c|}{ Anti-Fibronectin IgG } & \multicolumn{2}{|c|}{$\begin{array}{l}\text { Anti-von Willebrand } \\
\text { factor IgG }\end{array}$} \\
\hline & & & \multicolumn{2}{|c|}{$\mu g / m l$} & \multicolumn{2}{|c|}{$\mu g / m l$} & \multicolumn{2}{|c|}{$\mu g / m l$} \\
\hline & & & 6 & 60 & 6 & 60 & 6 & 60 \\
\hline & & & \multicolumn{6}{|c|}{$\times 10^{-3}$} \\
\hline \multicolumn{9}{|l|}{ FN adhesion } \\
\hline 9 & НCT8 & $7.5 \pm 1.1$ & $7.0 \pm 1.4$ & & $2.1 \pm 0.5$ & & $6.4 \pm 2.4$ & \\
\hline 3 & CT26 & $7.9 \pm 2.0$ & $9.8 \pm 3.7$ & & $3.7 \pm 1.8$ & & $8.7 \pm 4.9$ & \\
\hline 1 & HM54 & 34.0 & 37.1 & 41.3 & 38.9 & 7.1 & 37.4 & 37.2 \\
\hline 1 & HM54 & 71.1 & & & 47.4 & 0.6 & & \\
\hline \multicolumn{9}{|c|}{$\begin{array}{l}\text { von Willebrand factor } \\
\text { adhesion }\end{array}$} \\
\hline 6 & HCT8 & $4.5 \pm 0.9$ & $4.5 \pm 0.9$ & & $4.6 \pm 1.1$ & & $1.7 \pm 0.24$ & \\
\hline 8 & CT26 & $10.6 \pm 2.2$ & $11.1 \pm 2.2$ & & $9.6 \pm 2.0$ & & $5.4 \pm 1.0$ & \\
\hline 5 & HM29 & $7.2 \pm 1.9$ & $6.8 \pm 2.6$ & & $6.2 \pm 2.7$ & & $3.8 \pm 1.3$ & \\
\hline
\end{tabular}

Purified fibronectin in PBS was applied to microtiter wells at $1.25 \mu \mathrm{g}$ per well for HCT8 and CT26 cells and $0.5 \mu \mathrm{g}$ per well for HM54 cells overnight at $4^{\circ} \mathrm{C}$. Purified vWF was applied to wells at $6 \mu \mathrm{g}$ per well. Wells were then washed and blocked with PBS- $1 \%$ BSA before the addition of rabbit IgG for $1 \mathrm{~h}$ at $37^{\circ} \mathrm{C}$, followed by washing. $1 \times 10^{5}$ tumor cells were then added per well for $1 \mathrm{~h}$ at $37^{\circ} \mathrm{C}$ and washed with the above buffer, and adherent tumor cells removed with trypsin-EDTA and counted, as in Fig. 1.

carcinomas, and one squamous cell carcinoma. The effect of thrombin was specific in that it could be inhibited with specific inhibitors of thrombin such as hirudin and DAPA. The thrombin effect appeared to require the active proteolytic site since it could be abolished by modification of its active site with PPACK-thrombin or TPCK-thrombin; although this could have been a steric effect on receptor occupancy. The thrombin effect was highly sensitive with certain tumor cells. As little as $1-10 \mathrm{mU} / \mathrm{ml}(1-10 \%$ of the pathophysiologic concentration of thrombin) was capable of stimulating HM54 tumor cell ad- hesion. Indeed, $1,000 \mathrm{mU} / \mathrm{ml}$ was often inhibitory suggesting a conformational change of the thrombin receptor(s) at high concentration of receptor occupancy or a species of low-affinity thrombin inhibitory receptors. The thrombin effect required high-affinity receptors since PPACK-thrombin which binds to high as well as moderate- and low-affinity platelet receptors $(17,18)$ was capable of inhibiting the effect of active thrombin, whereas TLCK-thrombin which binds to moderateand low-affinity receptors was not $(17,18)$. Jamieson and coworkers $(17,18)$ have reported that platelet activation by

Table IV. Effect of Thrombin on Pulmonary Metastases of CT26 Colon Carcinoma and B16a Amelanotic Melanoma Tumor Cells

\begin{tabular}{|c|c|c|c|c|c|c|c|}
\hline Expt. & $n$ & Group & $\begin{array}{c}\text { Mean No. of } \\
\text { nodules per lung }\end{array}$ & $\begin{array}{c}\text { Mean nodule } \\
\text { volume per lung }\end{array}$ & Tumor mass & $\begin{array}{c}\text { Fold } \\
\text { increase }\end{array}$ & $P$ \\
\hline & & & & $\mathrm{mm}^{3}$ & & & \\
\hline \multicolumn{8}{|c|}{ CT26 colon carcinoma } \\
\hline \multirow[t]{2}{*}{1} & 19 & Control & $0.68 \pm 0.17$ & $9.1 \pm 3.8$ & 6.2 & & $=0.007$ \\
\hline & 20 & Thrombin & $1.95 \pm 0.40$ & $13.6 \pm 4.4$ & 26.5 & 4.3 & \\
\hline \multicolumn{8}{|c|}{ B16 Amelanotic melanoma } \\
\hline \multirow[t]{2}{*}{2} & 7 & Control & $2.1 \pm 0.6$ & $3.3 \pm 1.3$ & 6.9 & & $=0.006$ \\
\hline & 6 & Thrombin & $11.3 \pm 2.9$ & $41.7 \pm 6.0$ & 471.2 & 68 & $=0.016$ \\
\hline \multirow[t]{2}{*}{ Expt. } & $n$ & Group & $\begin{array}{l}\text { Mean No. of } \\
\text { nodules per section }\end{array}$ & $\begin{array}{c}\text { Mean surface } \\
\text { area per histologic } \\
\text { section }\end{array}$ & $\begin{array}{l}\text { Total tumor } \\
\text { area per histologic } \\
\text { section }\end{array}$ & & \\
\hline & & & & $\mu m^{2}$ & & & \\
\hline \multirow[t]{2}{*}{3} & 19 & Control & $0.37 \pm 0.17$ & $11.8 \pm 6.0$ & 3.1 & & $<0.001$ \\
\hline & 17 & Thrombin & $3.71 \pm 0.60$ & $330 \pm 71$ & 1237.5 & 413 & $<0.001$ \\
\hline
\end{tabular}

50,000 viable CT26 colon carcinoma cells plus $500 \mathrm{Mu}$ thrombin and 25,000 B16a amelanotic melanoma cells plus $250 \mathrm{Mu}$ thrombin were injected i.v. into $B A L B / \mathrm{c}$ and $\mathrm{C} 57 \mathrm{Bl} / 6 \mathrm{~J}$ mice, respectively. The number and volume of pulmonary metastases were enumerated macroscopically (expts. 1 and 2) and microscopically (expt. 3) on day 28. SEM is given. The first $P$ value refers to the difference between control and thrombin mean number of nodules per lung, the second value refers to the difference between mean nodule volume (or mean surface area per histologic section) per lung. 
thrombin is a receptor-mediated event. Their recently reported $K_{d_{1}}$ for high-affinity PPACK-thrombin is $0.3 \mathrm{nM}$ (18). This is compatible with our observed maximal thrombin-stimulated effect at $1-2.5 \mathrm{nM}$, equivalent to $100-250 \mathrm{mU} / \mathrm{ml}$.

The mechanism of thrombin activation of platelet-tumor cell adhesion is of particular interest, since it requires active thrombin on the platelet surface. Inactivation of bound thrombin by DAPA prevents the stimulatory effect of thrombin over basal binding of tumor cells to platelets. This would suggest that active thrombin is required for its enhanced effect on tumor cell adhesion, possibly by activation of the tumor cell surface to bind to platelets. This could be accomplished by altering or inducing tumor cell adhesive protein receptors (integrins) recently reported to be present on melanoma cells (24-27) and other tumors $(28,29)$. Our preliminary studies $(30)$ indicate that thrombin can activate tumor cells per se to bind to nonthrombin-treated platelets, support this suggestion. Thus these data are compatible with the following working hypothesis: tumor cells bind to adherent platelets via the interaction of tumor cell integrins and/or adhesive ligands with the platelet adhesive proteins fibronectin and von Willebrand factor. This is supported by the following observations: (a) Tumor cells have receptors for adhesive ligands. The tumor cells employed in this study as well as our previous report (4) bind to fibronectin or von Willebrand factor. ${ }^{2}$ Similar binding of a human melanoma cell to fibronectin and von Willebrand factor has recently been reported (25). Employing a human melanoma cell line (SK-MEL-28) that binds to platelets, we have identified receptors for fibronectin $\left(\alpha_{3} \beta 1\right)$ and vitronectin $\left(\alpha_{\mathrm{v}} \beta 3\right)$ by fluorescence flow cytometry, employing monoclonal antibodies specific for these receptors or their subunits (A. Klepfish and S. Karpatkin, unpublished data). ${ }^{3}$ An immunologically related GPIIb-GPIIIa complex has recently been reported for two human cell lines (cervical carcinoma, MS751 and colon carcinoma, clone A) that is required for binding to fibronectin (31). (b) Fibronectin and von Willebrand factor are anchored to the platelet by the platelet integrin GPIIb-GPIIIa $(5,6)$. Adherent platelets have these ligands on their surface (8). (c) Monoclonal antibody 10E5, RGDS, and $\gamma$ chain fibrinogen decapeptide, agents that block the binding of adhesive RGD domain ligands, fibronectin, and von Willebrand factor to GPIIb-GPIIIa, inhibit the thrombin-stimulated adhesion reaction. $(d)$ Thrombin treatment increases the surface density of GPIIb-GPIIIa, fibronectin, and von Willebrand factor. (e) Antibodies directed against GPIIb-GPIIIa, fibronectin or von Willebrand factor inhibit the thrombin-stimulated adhesion reaction.

It is of interest in this regard that oncogenically transformed rat malignant tumor cells lose most of their surface fibronectin and show decreased adherence to substratum $(28,32)$. This is thought to be secondary to a reduction in a surface integrin for fibronectin, $\alpha_{5} \beta_{1}$, in three transformed rat cell lines (28). However, exogenous fibronectin at higher levels can often restore this effect $(33,34)$, probably owing to the presence of lower-affinity $\alpha_{3} \beta_{1}$ fibronectin receptors (28). Human transformed fi-

2. We have been unable to demonstrate binding of HM29 tumor cells to fibrinogen or fibrin at a concentration of $5 \mu \mathrm{g} /$ well (data not shown). 3. Monoclonal antibodies were kindly supplied by Dr. W. G. Carter, Fred Hutchinson Cancer Center, Seattle, WA (AIA5, anti- $\beta 1$ and PB15, anti- $\alpha_{3} \beta 1$ ) and Dr. D. Cheresh, Scripps Clinic, CA (LM-142 and LM-609, anti- $\alpha_{\mathrm{v}}$ and anti- $\alpha_{\mathrm{v}} \beta 1$, respectively). broblasts do not lose their surface fibronectin receptor $(35,36)$, although they do appear to have a different cell surface distribution which could possibly affect their interaction with substratum fibronectin (36). We propose that the platelet surface can supply the exogenous fibronectin and/or von Willebrand factor surface necessary for malignant tumor cell adhesion and/or reconstitution of impaired adhesion.

Of note was the observation that either anti-fibronectin or anti-von Willebrand factor antibody completely inhibited thrombin-enhanced adhesion to platelets (Fig. 5), and that adhesion of tumor cells to fibronectin in vitro was associated with tumor cell spreading, whereas adhesion to von Willebrand factor was not. These observations are compatible with the possible requirement of a multiple-hit hypothesis for tumor-platelet adhesion, wherein initial adhesion is made via cell contact to adhesive ligand (von Willebrand factor) and more permanent adhesion is made via cell spreading (fibronectin).

The pathophysiologic relevance of these in vitro observations is supported by our in vivo studies. In three sets of experiments, in vivo thrombin given at approximately the same concentration required for in vitro enhancement of adhesion (i.e., $250-500 \mathrm{mU}$ per animal or ca. $125-250 \mathrm{mU} / \mathrm{ml}$ of intravascular volume), enhanced pulmonary metastasis 4-68-fold by macroscopic observation for CT26 and B16a tumor cells, respectively, and 413-fold by microscopic observation for B16a tumor cells.

Extrapolating from these data, it is possible that low-grade thrombin generation may be harmful to some patients with malignancies, since it may predispose to metastatic progression of the lesion. Indeed, there is abundant evidence that many tumor cells activate the coagulation system with generation of thrombin (37). Low-grade intravascular coagulation as diagnosed by increased fibrinogen turnover (38) increased plasma levels of fibrinogen/fibrin-related antigen (38) and increased plasma levels of fibrinopeptide $A$ has been observed in most patients with solid tumors (39-41). One study noted elevated fibrinopeptide-A levels in $60 \%$ of patients at time of presentation with increasing levels noted with progression of disease. Persistent elevation was associated with a poor prognosis (41).

Thus it is suggested that anti-thrombin and anti-platelet adhesive agents may be helpful in the prevention of tumor metastasis.

\section{Acknowledgments}

The authors are indebted to Ms. Judith Kallman for preparing the histologic sections and to Ms. Evelyn Marrero for typing the manuscript.

This study was supported by grant HL-13336-19 from the National Heart Lung and Blood Institute, and a grant from Centocor, Malvern, PA.

\section{References}

1. Gasic, G. J., T. B. Gasic, and C. C. Stewart. 1968. Antimetastatic effects associated with platelet reduction. Proc. Natl. Acad. Sci. USA. 61:46-52.

2. Pearlstein, E., C. Ambrogio, and S. Karpatkin. 1984. Effect of anti-platelet antibody on the development of pulmonary metastases following injection of CT26 colon adenocarcinoma, Lewis lung carcinoma, and B16 amelanotic melanoma tumor cells into mice. Cancer Res. 44:3884-3887.

3. Gasic, G. J., T. B. Gasic, N. Galanti, T. Johnson, and S. Murphy. 1973. Platelet-tumor cell interactions in mice: The role of platelets in the spread of malignant disease. Int. J. Cancer. 11:704-718.

4. Karpatkin, S., E. Pearlstein, C. Ambrogio, and B. S. Coller. 1988. Role of adhesive proteins in platelet tumor interaction in vitro and metastasis formation in vivo. J. Clin. Invest. 81:1012-1019. 
5. Plow, E. F., A. H. Srouji, D. Meyer, G. Marguerie, and M. H. Ginsberg. 1984. Evidence that three adhesive proteins interact with a common recognition site on activated platelets. J. Biol. Chem. 259:5388-5391.

6. Plow, E. F., R. P. McEver, B. S. Coller, V. L. Woods, Jr., G. A. Marguerie, and M. H. Ginsberg. 1985. Related binding mechanisms for fibrinogen, fibronectin, von Willebrand factor, and thrombospondin on thrombin-stimulated human platelets. Blood. 66:724-727.

7. Humphries, M. J., K. Olden, and K. M. Yamada. 1986. A synthetic peptide from fibronectin inhibits experimental metastasis of murine melanoma cells. Science (Wash. DC). 233:467-470.

8. Lahav, J., and R. O. Hynes. 1981. Involvement of fibronectin, von Willebrand factor, and fibrinogen in platelet interaction with solid substrate. J. Supramol. Struct. Cell. Biochem. 17:299-311.

9. Niiya, K., E. Hodson, R. Bader, V. Byers-Ward, J. A. Koziol, E. F. Plow, and $Z$. M. Ruggeri. 1987. Increased surface expression of the membrane glycoprotein IIb/IIIa complex induced by platelet activation: relationship to the binding of fibrinogen and platelet aggregation. Blood. 70:475-483.

10. Woods, V. L., Jr., L. E. Wolff, and D. M. Keller. 1986. Resting platelets contain a substantial centrally located pool of glycoprotein Ilb-IIla complex which may be accessible to some but not other extracellular proteins. J. Biol. Chem. 261:15242-15251.

11. Lerner, W. A., E. Pearistein, C. Ambrogio, and S. Karpatkin. 1983. A new mechanism for tumor-induced platelet aggregation: comparison with mechanisms shared by other tumors with possible pharmacologic strategy toward prevention of metastases. Int. J. Cancer. 31:463-469.

12. Kaneko, T., and G. A. LePage. 1978. Growth characteristics and drug responses of a murine lung carcinoma in vitro and in vivo. Cancer Res. 38:20842090.

13. Coller, B. S., E. I. Peerschke, L. E. Scudder, and C. A. Sullivan. 1983. A murine monoclonal antibody that completely blocks the binding of fibrinogen to platelets, produces a thrombasthenic-like state in normal platelets and binds to glycoproteins Ilb and/or IIIa. J. Clin. Invest. 72:325-338.

14. Coller, B. S., E. I. Peerschke, L. E. Scudder, and C. A. Sullivan. 1983. Studies with a murine monoclonal antibody that abolishes ristocetin-induced binding of von Willebrand factor to platelets: Additional evidence in support of GPIb as a platelet receptor for von Willebrand factor. Blood. 61:99-110.

15. Thorell, L., and B. Blomback. 1984. Purification of the factor VIII complex. Thromb. Res. 35:431-450.

16. Nesheim, M. E., F. G. Prendergast, and K. G. Mann. 1979. Interactions of a fluorescent active-site-directed inhibitor of thrombin: dansylarginine- $\mathrm{N}-(3$ ethyl-1,5-pentanediyl) amide. Biochemistry. 18:996-1003.

17. Harmon, J. T., and G. A. Jamieson. 1986. Activation of platelets by $\alpha$-thrombin is a receptor mediated event: D-phenylalanyl-L-propyl-L-arginine chloromethyl ketone-thrombin, but not $N$-tosyl-L-lysine chloromethyl ketonethrombin, binds to the high affinity thrombin receptor. J. Biol. Chem. 34:15928 15933

18. Jamieson, G. A. 1988. The activation of platelets by thrombin: a model for activation by high and moderate affinity receptor pathways in platelet membrane receptors. In Molecular Biology, Immunology, Biochemistry and Pathology

G. A. Jamieson, editor. Alan R. Liss, Inc., New York. 137-158.

19. Workman, E. F., Jr., G. C. White II, and R. L. Lundblad. 1977. Structurefunction relationships in the interaction of thrombin with blood platelets. J. Biol. Chem. 252:7118-7123.

20. Lyman, B., L. Rosenberg, and S. Karpatkin. 1971. Biochemical and bio physical aspects of human platelet adhesion to collagen fibers. J. Clin. Invest 50:1854-1863.

21. Shulman, S., and Karpatkin, S. 1980. Crossed immunoelectrophoresis of human platelet membranes: diminished major antigen in Glanzmann's thrombasthenia and Bernard-Soulier syndrome. J. Biol. Chem. 255:4320-4327.

22. Fitzgerald, L. A., B. Leung, and D. R. Phillips. 1985. A method for purify- ing the platelet membrane glycoprotein IIb-IIIa complex. Anal. Biochem. 151:169-177.

23. Karpatkin, S., C. Ambrogio, and E. Pearlstein. 1984. Lack of effect of in vivo prostacyclin on the development of pulmonary metastases in mice following intravenous injection of CT26 colon carcinoma, Lewis lung carcinoma, or B16 amelanotic melanoma cells. Cancer Res. 44:3880-3883.

24. Rieber, M., A. Gross, and M. S. Rieber. 1987. Relationship of a $M_{r} 140$ fibronectin receptor and other adhesion-related glycoproteins to tumor cell-cell interaction. Cancer Res. 47:5127-5131.

25. Cheresh, D. A., and R. C. Spiro. 1987. Biosynthetic and functional properties of an arg-gly-asp-directed receptor involved in human melanoma cell attachment to vitronectin, fibrinogen and von Willebrand factor. J. Biol. Chem. 262:17703-17711.

26. Gehlsen, K. R., W. S. Argraves, M. D. Pierschbacher, and E. Ruoslahti. 1988. Inhibition of in vitro tumor cell invasion by arg-gly-asp-containing synthetic peptides. J. Cell Biol. 106:925-930.

27. Kramer, R. H., K. A. McDonald, E. Crowley, D. M. Ramos, and C. H. Damsky. 1989. Melanoma cell adhesion to basement membrane mediated by integrin-related complexes. Cancer Res. 49:393-402.

28. Plantefaber, L. C., and R. E. Hynes. 1989. Changes in integrin receptors on oncogenically transformed cells. Cell. 56:281-290.

29. Cheresh, D. A., J. W. Smith, H. M. Cooper, and V. Quaranta. 1989. A novel vitronectin receptor integrin $(\alpha \mathbf{v} \mathbf{x})$ is responsible for distinct adhesive properties of carcinoma cells. Cell. 57:59-69.

30. Nierodzik, M. L., A. Plotkin, and S. Karpatkin. 1989. Thrombin stimulates both platelets and tumor cells to adhere to each other. Clin. Res. 37:548A (Abstr.)

31. Grossi, I. M., J. S. Hatfield, L. A. Fitzgerald, M. Newcombe, J. D. Taylor, and K. V. Honn. 1988. Role of tumor cell glycoproteins immunogically related to glycoproteins Ib and IIb/IIla in tumor cell-platelet and tumor cell-matrix interactions. FASEB (Fed. Am. Soc. Exp. Biol.) J. 2:2385-2395.

32. Yamada, K. M. 1983. Cell surface interactions with extracellular materials. Annu. Rev. Biochem. 52:761-799.

33. Yamada, K. M., S. S. Yamada, and I. Pastan. 1976. Cell surface protein practically restores morphology, adhesiveness, and contact inhibition of movement to transformed fibroblasts. Proc. Natl. Acad. Sci. USA. 73:1217-1221.

34. Ali, I., V. Mautner, R. Lanza, and R. O. Hynes. 1977. Restoration of normal morphology, adhesion and cytoskeleton in transformed cells by addition of a transformation-sensitive surface protein. Cell. 11:115-116.

35. Ylanne, J., and I. Virtanen. 1989. The $M_{\mathrm{r}} 140,000$ fibronectin receptor complex in normal and virus-transformed human fibroblasts and in fibrosarcoma cells: identical localization and function. Int. J. Cancer. 43:1126-1136.

36. Akiyama, S. K., H. Larjava, and K. M. Yamada. 1990. Differences in the biosynthesis and localization of the fibronectin receptor in normal and transformed cultured human cells. Cancer Res. 50:1601-1607.

37. Honn, K. V., B. F. Sloane, and P. G. Cavanaugh. 1988. Role of the coagulation system in tumor-cell-induced platelet aggregation and metastasis. Haemostasis. 18:37-46.

38. Yoda, Y, and T. Abe 1981. Fibrinopeptide A (FPA) level and fibrinogen kinetics in patients with malignant disease. Thromb. Haemostasis. 46:706-709.

39. Merskey, C., A. J. Johnson, J. U. Harris, M. T. Wang, and S. Swain. 1980 Isolation of fibrinogen-fibrin related antigen from human plasma by immune-affinity chromatography: its characterization in normal subjects and in defibrinating patients with abruptio placentae and disseminated cancer. Br. J. Haematol. 44:655-670.

40. Peuscher, F. W., F. J. Cleton, L. Armstrong, E. A. Stoepman-van Dalen J. A. van Mourik, and W. G. van Aken. 1980. Significance of plasma fibrinopeptide A (FPA) in patients with malignancy. J. Lab. Clin. Med. 96:5-14.

41. Rickles, F. R., R. C. Edwards, C. Barb, and M. Cronlund. 1983. Abnormalities of blood coagulation in patients with cancer: fibrinopeptide $A$ generation and tumor growth. Cancer. 51:301-307. 